\title{
WOMEN AND DIVORCE IN PONOROGO, EAST JAVA: Responsibility of The Husband in The Family
}

\author{
M. Harir Muzakki', Ali Akhbar Abaib Mas Rabbani Lubis², Anis Hidayatul Imtinah³ \\ ${ }^{1,3}$ Faculty of Sharia, State Institute for Islamic Studies (IAIN) Ponorogo, Jawa Timur, Indonesia \\ Jl. Pramuka No. 156 Ronowijayan, Siman, Ponorogo, Jawa Timur \\ E-mail: harir.zdzo6@gmail.com, anis.hidayatulhanah@gmail.com \\ 2Post-graduate Program, State Islamic University (UIN) Sunan Kalijaga, Yogyakarta, Indonesia \\ Jl. Laksda Adisucipto, Daerah Istimewa Yogyakarta \\ E-mail: lubismymarga@gmail.com
}

\begin{abstract}
A divorce is closely related to the absence of the husband's responsibility in a family. A wife has no right to propose divorce as long as the husband, as the head of the family, can carry out his obligations materially and non-materially. This paper tries to reveal why women propose divorce and how wives view their husbands' responsibilities as the family's head. This article results from field research in the Ponorogo District and uses data derived from interviews with eight female informants who proposed a legal divorce. As the head of the family, a husband has both material and nonmaterial responsibilities to his wife. This responsibility is the husband's obligation to his wife that must be fulfilled. The husband's material obligations are to provide a living, which includes feeding, providing shelter, and clothing. Meanwhile, the nonmaterial duties are to educate, guide, protect, love, and respect. The results of this study indicate that the wives proposed for legal divorce because their husbands, as to the head of the family, do not carry out their material responsibilities; that is, they do not fulfill their obligation to provide livings for their wife. Husbands also do not meet their nonmaterial duties to their wives.
\end{abstract}

Keywords: wife; divorcee; husband; income; responsibility.

\begin{abstract}
Abstrak: Cerai gugat terkait erat dengan tidak adanya tanggung jawab suami dalam sebuah keluarga. Pada dasarnya, seorang istri tidak berhak mengajukan cerai gugat selama suami sebagai kepala keluarga dapat melaksanakan kewajibannya secara material dan non material. Artikel ini ingin mengungkap mengapa perempuan mengajukan cerai gugat dan bagaimana pandangan istri terhadap tanggung jawab suami sebagai kepala keluarga. Artikel ini merupakan hasil penelitian lapangan di Kapubaten Ponorogo dan menggunakan data yang bersumber dari hasil wawancara dengan delapan informan perempuan yang mengajukan cerai gugat. Seorang suami sebagai kepala keluarga memiliki tanggung jawab material dan non material kepada istri. Tanggung jawab tersebut merupakan kewajiban suami terhadap istri yang harus ditunaikan. Adapun kewajiban suami yang bersifat material adalah memberi nafkah yang meliputi memberi makan, menyediakan tempat tinggal dan pakaian. Sedangkan kewajiban bersifat non material adalah mendidik, membimbing, melindungi, menyayangi dan menghargai. Hasil penelitian ini menunjukkan bahwa para istri mengajukan cerai gugat karena suami sebagai kepala keluarga tidak bertanggung jawab secara material, yakni tidak menunaikan kewajibannya memberi nafkah kepada istri. Para suami juga tidak menjalankan kewajibannya non material kepada istrinya.
\end{abstract}

Kata kunci: istri; cerai gugat; suami; nafkah; tanggung jawab.

\section{Introduction}

A divorce is an initiative of the wife to end the household relationship with her husband. The number of divorce cases in Ponorogo Regency has always increased every year. Most of those who file for legal divorce work as TKW (Tenaga Kerja Wanita/female workers) abroad. In East Java, the number of TKW from Ponorogo as of January to the end of September 2016 was 3,662, with 17 people working in Brunei Darussalam, 
975 people in Hong Kong, 182 in Malaysia, 154 in Singapore, and 2,334 in Taiwan. ${ }^{1}$ According to Abdullah Sofyandi, nationally, in a divorce case with a background in the overseas labor profession, Ponorogo is in Indonesia's third rank.

The wives who filed for divorce mostly based on economic reasons. The TKW returned to their hometowns, bringing a lot of money and living an urban lifestyle. Meanwhile, when they returned to their hometown, the TKW saw the condition of their husbands working in moderation. This condition makes TKW feel they have a much higher income than their husbands. ${ }^{2}$ The second reason is the affair that afflicts the husband or the TKW itself. Usually, migrant workers divorce their husbands because they find that their partners have taken another woman when returning to their hometowns. ${ }^{3}$ TKW files most divorce cases because they feel that their husbands are not responsible and do not provide for their families.

The high number of claiming divorce cases in Ponorogo district is partly because the husband is not responsible. Husbands allow, and allow, even ask their wives to become TKW. It is also possible that the wife herself has a strong desire to become a TKW because the husband's income is minimal, so that it is not enough to meet the needs of the wife and family. This husband's income makes the wifeless able to accept and live life with her husband as it is, and the wife feels dissatisfied with the income provided by her husband.

The divorce case in Ponorogo illustrates the large number of problematic marriages in Ponorogo. Divorce is the culmination of a lousy marriage adjustment and occurs when

${ }^{1}$ Abdullah Shofwandi told Kompas.com that from the 2000 divorce cases handled, forty per cent of the plaintiffs had a background in the profession of foreign female workers. Read http://regional.kompas.com/read/2016/11/08/16443431/pemkab. ponorogo.buat.perda.larangan. tki.cerai.

2 Abdullah Sofyandi as the Head of Public Relations of PA Ponorogo is of the view that in addition to that when they return to their villages, they bring abundant income. This can be a trigger for the appearance of cracks in the household so that the household becomes disharmonious. Read http://www. jawapos.com/read/2016/07/31/42267/enam-bulan-ada-seribu-jan da-baru-di-ponorogo.

3 http://regional.kompas.com/read/2016/11/08/16443431/ pemkab.ponorogo.buat.perda.la rangan.tki.cerai. the husband and wife are no longer able to find solutions to problems that can satisfy both parties. Divorce is a fact that happens between married couples due to differences in principles that cannot reconcile through various ways in family life. Each of them maintains his stand, desire, and will without trying to give in to achieve family integrity. The unwillingness and inability to acknowledge the shortcomings of oneself and one's partner cause a trivial problem to become so big that it ends in a divorce.

The wives who filed for divorce indicate that there are problems in the household that cannot resolve it. It can identify because of the transformation of women's gender awareness and understanding, such as Isnatin Ulfah's research on a divorce suit in Ponorogo, starting from data collection conducted from 2007 to 2010. The large number of wives filing for divorce indicates increasing gender awareness due to the patriarchal culture that leads to discrimination, subordination, marginalization, and gender-based violence. ${ }^{4}$

Rohana Muawwanah examines the divorce suit's reality for TKW (East Asia) in Ponorogo Regency. The result was that the reasons for using the East Asian TKW for divorce to the Ponorogo Regency Religious Court, which used the basis for the lawsuit, were due to economic factors or not providing a living, husbands imprisoned, infidelity, gambling, unknown husbands, and disharmony. However, the real reason for East Asian TKW is economic, environmental/social factors, lifestyle, personal responsibility, and other supporting factors such as education, family, and technology. The results in the view of Islamic law regarding the case are grouped into three groups: permissible (permissible) because of the consideration of benefit and makruh or haram because of divorce suit based on the plaintiff's unclearness. ${ }^{5}$

${ }^{4}$ Isnatin Ulfah, "Menggugat Perkawinan: Transformasi Kesadaran Gender Perempuan dan Implikasinya terhadap Tingginya Gugat Cerai di Ponorogo", Kodifikasia, vol.5, no. 1 (2010), pp.1-22.

${ }^{5}$ Rohana Muawwanah, "Relitas Gugat Cerai TKW (Asia Timur) di Kabupaten Ponorogo: Sebuah Tinjauan Hukum Islam", Edugama: Jurnal Kependidikan dan Sosial Keagamaan", vol. 5, No.2 Desember (2019), pp. 154-182. 
Indah Purwati wrote about a legal divorce in Jenangan Ponorogo District. The wives filed for divorce because their husbands are not economically responsible, leaving their obligations, unhealthy polygamy, persecution, unexpected third-party interference, and husbands experiencing a moral crisis. ${ }^{6}$ Dewi Permatasari's article concludes that the wives who file for legal divorce in Malang's city caused ethical crisis factors, livelihoods, partner loyalty, and emotional discomfort. The most dominant factor is emotional discomfort in the decision-making process to file a legal divorce.? Budhy Prianto et al.'s research shows that what causes divorce is the absence of three types of marital commitment by the partner: personal responsibility, moral obligation, and structural duty. ${ }^{8}$

Based on the literature review results above, the author did not find topics about the object and focus of the discussion with which the researcher was going to do it. In this paper, the issue discussed is the wife's view of the husband's responsibility as a family leader. How is a picture of the wife who filed for divorce against her material and nonmaterial duties as the family's head?

\section{Method}

This paper is the result of field research with a qualitative approach using interview data sources and documentation. Researchers interviewed eight wives as informants who filed for a legal divorce. Meanwhile, the data source was from Posbakum (Pos Bantuan Hukum/Legal Aid Post) regarding the informant's identity and the reasons for filing for a legal divorce, articles about divorce published in scientific journals, news about the divorce in Ponorogo Regency.

${ }^{6}$ Indah Purwati, "Persepsi Pelaku Gugat Cerai terhadap Alasan Perceraian di Kecamatan Jenengan (Implementasi UU No. 1 Tahun 1974", Skripsi, STAIN Ponorogo, (2011).

7 Dewi Permatasari, "Faktor-faktor yang Melatarbelakangi Pengambilan Keputusan Seorang Isteri untuk Mengajukan Gugatan Cerai", Skripsi, Psychology Study Program, Department of Guidance, Counseling and Psychology, Faculty of Education, State University of Malang, (2009).

8 Budhy Prianto, Nawang Warsi Wulandri, Agustin Rahmawati, "Rendahnya Komitmen dalam Perkawinan sebagai Sebab Perceraian" Jurnal Komunitas: International Journal of Indonesian Society and Culture, Vol.5, No.2 (2013), pp. 208-218.
This research took place in Ponorogo Regency. Location selection base on two considerations: Ponorogo Regency has the largest number of TKW in East Java and the high number of divorce cases in Ponorogo Regency.

\section{Material Obligations of the Husband}

An obligation is something that needs to be given, either in the form of an object or an act. ${ }^{9}$ The husband's wife's responsibility is a right received by the wife, including material and nonmaterial obligations, including material rights, namely dowry, and income. In the Islamic tradition, dowry is an essential thing for a man to give to his partner, while what is not material is treating his wife well and being fair. ${ }^{10}$ The primary obligations of the husband to his wife that are material or material are:

\section{Dowry (Mahar)}

A dowry is a mandatory gift declared by a future husband to his wife in the marriage contract. The dowry is a sign of their agreement and their willingness to live as husband and wife. According to Imam Syafi'i, a prospective husband must be given a dowry to a future wife to control all his body members." Mahar in the Islamic tradition is also used as one of the requirements in the practice of mu'tah marriage and the way of local traditional weddings, for example, the Muslim community in Bima. The latter knows him with the term co'i. ${ }^{12}$ One important note is that the scholars have agreed that the dowry is a legal condition of marriage, and it is not permissible to agree to abolish the dowry.

9 Idris Ahmad, Fiqh Syafi'l, (Jakarta: Karya Indah, 1986), pp. 341-342.

${ }^{10}$ Wahbah Al-Zuhaili, Al-Fiqh Al-Islam wa Adillatuh, (Kairo: Dar Al-Fikr, 1989), Juz. VII, p. 327.

${ }^{11}$ Abdurrahman Al-Jaziri, Al-Figh 'Ala Madzahib Al-Arba'ah, (Beirut: Dar al-Fikr, t.th), Juz. IV, p. 94. This dowry obligation is based on Q.S. al-Nisâ'[4]: 4 and 24.

${ }^{12}$ Atun Wardun in his research explained, "The Bimanese refer to the marriage payment as: 'co'l' (price or respect), which encompasses the mahr (co'i di pehe or stated payment), given as part of Islamic practice". Atun Wardatun, "The Social Practice of Mahr among Bimanese Muslims: Modifying Rules, Negotiating Roles", Edited by John R. Bowen and Arskal Salim, Women and Property Rights in Indonesian Islamic Legal Context, (Leiden: Brill, 2019), p. 17. 
The dowry is actual proof that the prospective husband loves his wife. The dowry is not to respect the future wife, but to offer a willing husband and sacrifice his assets to be handed over to his wife. Mahar is also a sign that the husband will continue to provide for his wife in the future in his household life. ${ }^{13}$

\section{Nafkah}

The word nafkah (livelihood) comes from the Arabic anfâqa-yunfiqu-infaqan (نفق-ينفق -انفا), 14 which means shopping or spending. ${ }^{15}$ In Indonesian, the term "nafkah" means expenditure. ${ }^{16}$ Another opinion states that the source of livelihood is the root word/noun (masdar), nafaqah. At the same time, the form of the verb is "nafaqa" which has the equivalent meaning of the verb dzahaba, kharaja, nafadza and madha (ذهب, خرج, نفد, مضى).17

According to the term, nafkah is an expense that a person uses for the person he is dependent on in making ends meet. Or in other words, everything that humans need in the form of clothing (kiswah), food (tha'am), and board (maskan). Thus, living as a root word/noun will mean something that is transferred and expended for a sure thing and a particular purpose, in the form of clothing, food, or shelter. The word nafaqah/infaq is only used in a positive sense. ${ }^{18}$

\section{Residence}

A husband is also obliged to provide the wife with a place to live. The husband and wife's home is suitable for habitation and the husband's ability to provide the necessary household equipment and services for daily needs. If described in detail, the residence includes three things: 1) Board, namely the house where the husband and wife live with their children, whether they own it, rent it, and so on. Husbands are obliged

${ }^{13}$ Wahbah Al-Zuhaili, Al-Fiqh Al-Islam..., p. 253.

${ }^{14}$ Luwis Ma'luf, Al-Munjid fi al-Lughat wa al A'lam, (Beirut: al-Syirkiyah, 1986), p. 828.

15 Ahmad Warson Munawir, Kamus al Munawwir, (Yogyakarta: Pondok Pesantren al-Munawir, 1984), p. 1548.

${ }^{16}$ Diknas, Kamus Besar Bahasa Indonesia, (Jakarta: Balai Pustaka, 2002), Ed. 3, p. 770.

${ }^{17}$ Al-Jâziriy, Al-Figh 'ala al-Madzahib al-Arba'ah, Jilid. IV, p. 260.

${ }^{18}$ Abu Bakar Muhammad Syatha, l'anah al- Thalibin, (Beirut: Dar al- Fikr, 2005), Juz. 4, p. 60. to protect their wives and children; 1) the wife must live in the house of the husband or the husband's appointment; 2) equipment needed for the household including living room, bedroom, kitchen equipment, and so on; 3). Energy or servants to serve and lighten the wife's workload if the conditions require it. A husband should not burden his wife with household chores beyond her ability without the help of a husband or someone else whose husband works for the wife's work. ${ }^{19}$

The Marriage Law regulates the husband's material obligations towards his wife, article 34 paragraph 1: The husband is obliged to protect his wife and provide all the necessities of household life by his abilities. The Compilation of Islamic Law (KHI) Article 80, sections 2 and 4, paragraph 2 states: The husband is obliged to protect his wife and provide all the necessities of household life according to his abilities. Then section 4 states: By his income, the husband bears: a. a living, clothes and a place to live for the wife; b. household costs, treatment costs, and medical expenses for the wife and children; c. education costs for children.

Regarding the husband's obligation to provide a place to live, the Compilation of Islamic Law regulates it in article 81:

(1) Husbands are obliged to provide a place of residence for the wife and children, or a former wife who is still in iddah;

(2) The residence is a suitable place to live for the wife while in the marriage bond, or in iddah talak or iddah death;

(3) The residence place protects the wife and children from interference by other parties to feel safe and at ease. The residence also functions as a place to store assets, as a place to organize and organize household items;

(4) The husband must complete a living place according to his abilities and the community's conditions where he lives, namely household equipment and other supporting facilities

${ }^{19}$ Zahry Hamid, Pokok-pokok Perkawinan Islam dan UndangUndang Perkawinan di Indonesia (Yogyakarta: Binacipta, 1978), p. 5 . 
The above explanation means: 1) The husband is obliged to provide a place to live for his wife and children, or a former wife who is still in iddah; 2) Residence is a suitable place to live for the wife while in the marriage bond, or iddah talak or iddah death; 3) The location of residence is provided to protect the wife and children from interference by other parties so that they feel safe and at ease. The home functions as a place to store assets, as a place to organize and organize household items; 4) The husband is obliged to complete the residence according to his ability and according to the conditioning environment he lives in, both in the form of household equipment and other supporting facilities.

Nonmaterial Obligations of the Husband

The obligations of husbands towards wives that are immaterial are: ${ }^{20}$

1. Husband is obliged to interact with his wife in the right way. It is based on the words of Allah Swt. Q.S. al-Nisâ'[4]: 19:

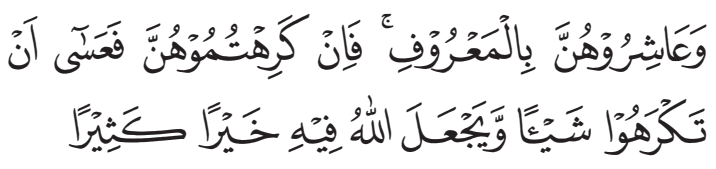

Having sex with a wife in the right way is meant to be nice to her, not to scold her in a way that exceeds the limits, let alone hit her, which negatively affects her. ${ }^{21}$ Husbands are obliged to protect and care for their wives, which means protecting their wives' honor, not to waste them, and to keep them always to carry out Allah's commands and stop all actions that are forbidden by Him.

2. Husbands who have more than one wife must be fair to their wives.

To act legally means to provide for his wives and determine his quantitative turns, such as the amount of income and the turn to fuck the wives, not fair in sharing the love because humans cannot control their hearts.

${ }^{20}$ Kamal Mukhtar, Asas-asas Hukum Islam Tentang Perkawinan, (Jakarta: Bulan Bintang, 1987), pp. 150-152.

${ }^{21}$ Dealing with wives in a good way (ma'ruf) includes three things. First, respect, treat well, increase religious knowledge and morals, as well as the necessary knowledge. Second, safeguard and protect the good name of the wife. Third, meet the needs of their biological nature. Azar Basyir, Hukum Perkawinan Islam, (Yogyakarta: UII, 1996), pp. 54-56.
Even so, the husband's inclination towards one wife results in the other wife's suffering or neglect.

The Marriage Law states the husband's nonmaterial obligation to his wife in Article 34 paragraph 1: Husbands are obliged to protect their wives and provide all the necessities of married life according to their abilities. Whereas in the Compilation of Islamic Law, there is in article 80, namely:

(1) A husband is a guide for his wife and household. However, the husband and wife together decide on essential household matters.

(2) Husbands are obliged to protect their wives and provide all the necessities of household life according to their abilities.

(3) Husbands are obliged to provide religious education to their wives and provide opportunities to learn useful and beneficial knowledge to religion and the nation.

(4) according to his income, the husband shall bear:

a. a living, clothes and a place to live for the wife;

b. household costs, treatment costs, and medical expenses for the wife and children;

c. education costs for children.

(5) The obligations of a husband towards his wife as referred to in paragraph (4) letters $a$ and $b$ above shall come into effect after his wife's perfect appearance.

(6) The wife can release her husband's obligations $s$ referred to in paragraph (4) letters $a$ and $b$.

(7) The husband's obligation, as meant in paragraph (5) shall be canceled if the wife is nusyuz.

The provisions regarding husband and wife's rights and obligations in the Compilation of Islamic Law are more systematic than in the Marriage Law. It is understandable because the Compilation of Islamic Law was formulated after 17 years since the Law was issued. Meanwhile, in the marriage regulation, the rights of husband and wife are more general. ${ }^{22}$

${ }_{22}$ Ahmad Rofiq, Hukum Islam di Indonesia (Jakarta: PT Raja Grafindo Persada, 1997), p. 185. 


\section{Wife's View of Husband's Material Obligations}

The author obtained data in the field through interviews with eight informants, but there were differences, especially regarding income from the husband. Some get a living from their husbands every month. ${ }^{23}$ Some feel that they have never been given a decent living. ${ }^{24}$ Some have never been given a living from the start of their marriage. ${ }^{25}$ Some are given a residence for only a year of marriage, after which they do not receive a living. These differences can show that income is a factor that is part of the harmony in the household.

In the explanation above, when viewed based on Q.S. al-Nisâ' [4]: 34, as follows:

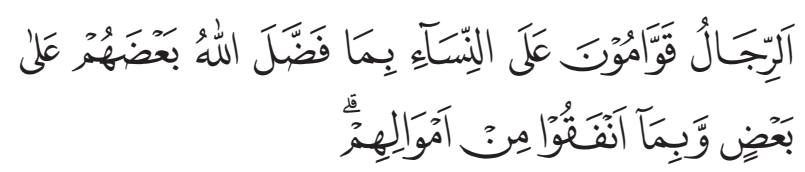

The scholars agree that the object aimed at the obligation to support is the husband. Therefore, this verse becomes the argument for a husband's responsibility to support his wife and family. ${ }^{26}$ The burden to provide for his wife is also explained by Allah Swt, in Q.S. al-Baqarah [2]: 233, as follows:

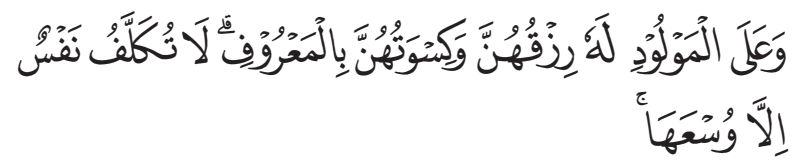

In a hadith narrated by Jabir r.a, Rasulullah, PBUH said: (at the time of performing the pilgrimage, he reminded husbands) about wives: the husband's duty is to feed, clothe his wife accordingly. ${ }^{27}$

The above verses and hadith clearly explain that a husband is obliged to provide a living to his wife. Even though the wife has a decent job and salary, the husband is still obliged to provide a living for his wife. The wife's salary earned from her work is the wife's right. A husband has no right to arrange and ask for his wife's salary unless his wife gives it voluntarily.

23 Tina, Interview, September 29, 2017.

${ }^{24}$ Mawar, Interview, September 30, 2017

${ }_{25}$ Anggrek, Interview, October 06, 2017.

${ }_{26}$ M.F. Zenrif, Realitas Keluarga Muslim antara Mitos dan Doktrin Agama, (Malang: UIN-Malang Press, 2008), p. 100.

${ }_{27}$ M.F. Zenrif, Realitas Keluarga Muslim..., p. 240.
The author found two informants who had never been given a living by their husbands from the interviews. The husband is neglecting his obligations as a husband and not to be a leader in the household. The husband becomes a home leader because he provides for the family and the advantages that Allah has given him as in Q.S al-Nisâ'[4]: 34.

A wife is allowed to take her husband's assets if the husband's provision of support for herself and her children is insufficient to meet her daily needs. It is as has been done by Hindun because her husband, named Sofwan is a stingy person. Hindun took her husband's property without her knowledge. This event is recorded in a hadith narrated by 'Aisyah, which means as follows: “From' Aisyah: Hindun said: O Messenger of Allah: Abu Sufyan (her husband) was a stingy person. He did not provide sufficient support for me and my child unless I took from him without his knowledge. So the Prophet replied: take what is enough for you and your child in a ma'ruf way". ${ }^{28}$

Even though the wife is allowed to take her stingy husband's assets as in the hadith above, the informants never took their husbands' assets. The informants who were wives did not dare to take their husband's assets. It is understandable because some wives are afraid of their husbands. The husbands are often rude towards their wives. ${ }^{29}$ At the same time, others leave their husbands who do not provide a living because they both have their income. ${ }^{30}$

The informants' husbands' economic conditions varied; some had jobs and regular income. Some had jobs, but their salary was uncertain, like working in a convection factory ${ }^{31}$ and an office boy (OB) at a motorcycle dealer..$^{32}$ Husbands who work in factories earn a living to their wives one million per month, while those who work as OB only support three hundred

\footnotetext{
${ }_{28}$ Al-Hafidz Ibnu Hajar al-Asqalani, Bulugh al-Maram (Bandung: PT al-Ma`arif, t.th.), p. 241.

29 Nining, Interview, October 01, 2017. Wati, Interview, October 04, 2017. Kenanga, Interview, October 02, 2017.

${ }^{30}$ Sakura, Interview, September 27, 2017. Mawar, Interview, September 30, 2017. Anggrek, Interview, October 06, 2017.

${ }^{31}$ Tina, Interview, September 29, 2107.

32 Sakura, Interview, September 29, 2017.
} 
thousand for three months as long as the family home. It's just that the husband's wives have jobs so that they can cover their daily needs. ${ }^{33}$ Even though the husbands' careers are diverse and their income is not too high, or according to their abilities, of course, it is by Q.S. al-Baqarah [2]: 268 as follows:

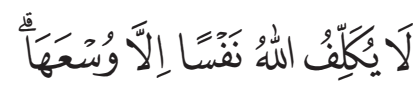

But the wives make up for these shortcomings by working. Even though the husband's income level is by his ability, the husband should try his hardest to fulfill the family's livelihood and work on it lawfully and obtain it in the right way. Also, husbands should not be stingy in providing for the people they depend on. It should also be noted that a wife can exempt her husband from the obligation of support, kiswah, shelter, household expenses, care, medication for the wife and child, except for the child's education. ${ }^{34}$ But this only applies if the wife is willing to waive this responsibility, as, in Article 80, paragraph (6) states: the wife can release her husband from the obligations towards her as referred to in paragraph (4) letters $a$ and $b$.

Even though informants still feel that they are sufficient to provide for their husbands' support. Still, some do not accept it because they only get a living from their husband of ten thousand per month; even so, the husband's daily needs for food are borne by the husband. ${ }^{35}$ As long as they are married, their husbands have never given their wife a living. ${ }^{36}$

The fuqaha differed from when a husband was obliged to provide for his wife. The Hanafiyah Ulama thinks that after a valid marriage contract, the husband must provide for his wife, even though a wife has not lived with her husband. There are several opinions, among which the result of a valid marriage contract is that a wife becomes her husband's prisoner. Suppose a wife refuses the husband's invitation to live together without any star's reason. In that case, she is not

33 Tina, Interview, September 29, 2017 and Sakura, Interview, October 09, 2017..

34 See Compilation of Islamic Law, Article 80, verse (4). Letter $\mathrm{a}, \mathrm{b}$, and $\mathrm{c}$.

35 Kenanga, Interview, October 03, 2017.

${ }^{36}$ Anggrek, Interview, October 06, 2017. entitled to earn a living because she is deemed to have committed insubordination (nusyuz). ${ }^{37}$

Ulama Syafi'iyah, Malikiyah and Hanabilah argue that husbands do not have an obligation to support their wives only because of the marriage contract. A husband begins to support his wife when he has sexual intercourse or after living together even though the wife asks to live together. It is different from the Ulama Dzahiriyah that the husband must provide for the wife after the marriage contract. Whether the wife allows her husband to intercourse with her or not, is still small or adult, is still a virgin or is a widow. ${ }^{38}$

After getting married, several informants lived directly with their husbands. Some of them were still living with their family sister at the beginning of the marriage; then, they decided to contract. In the first year of marriage, the husband pays the house's rent, but the pay is the wife in the following year. ${ }^{39}$ Some husbands live with their wife's parents (in-laws) until both of them divorce. There are also those who build the house as a result of wife work. ${ }^{40}$

The explanation above, when referring to the Compilation of Islamic Law, has previously been touched on in Article 81, paragraph (1) states:

(1) Husbands are obliged to provide a place to live for the wife and children or the former wife who is still in iddah;

(2) The residence is a suitable place to live for the wife while in the marriage bond, or in iddah talak or iddah death;

(3) The residence place protects the wife and children from interference by other parties to feel safe and at ease. The residence also functions as a place to store assets, as a place to organize and organize household items;

(4) The husband is obliged to complete the

${ }^{37}$ Satria Effendi M. Zein, Problematika Hukum Keluarga Islam Kontemporer, (Jakarta: Kencana, 2010), p. 155. This Hanafiyah opinion was strengthened by Sayyid Sabiq, a wife's authority was limited and its benefits were taken, so the husband was obliged to support it. Sayyid Sabiq, Fikih Sunnah, (Bandung: Alma'arif, 1997), Jilid. 7, p. 76.

${ }^{38}$ Amir Syarifuddin, Hukum Perkawinan Islam di Indonesia, (Jakarta: Kencana, 2009), $5^{\text {th }}$ print, p. 168.

39 Tina, Interview, September 29, 2017.

40 Sakura, Interview, October 09, 2017. 
residence according to his ability. According to the environment's condition, he lives in household equipment and other supporting facilities.

The interview results show that the wife feels that she has not received it because apart from daily living, the husband also does not provide a live place. Even wives build houses on the initiative and results of their work, such as TKW. ${ }^{41}$ Several other husbands live in the house of their in-laws..$^{42}$ It means that the five informant husbands are not responsible for providing a place to live for their wives or families. Meanwhile, a husband is responsible for providing a place to live by renting a house, even though the wife continues to pay for the following year's rented home. ${ }^{43}$

Relating to the husband's obligation to complete the residence according to his ability and according to the environment's condition, he lives in, both in household equipment and other supporting facilities. An informant initially wanted to fill household furniture with hopes from her husband, but his husband rejected it. ${ }^{44}$

The material obligations of a husband to his wife in the form of materials include buying clothes. Researchers found that husbands did not fulfill their obligation to purchase their wives' clothes in interviews with informants. Several informants bought their clothes, even because there were husbands who did not have a permanent job, so they often did not provide a living, especially buying clothes. Meanwhile, they have never been given birth support during their household, especially purchase clothes for themselves. ${ }^{45}$ Even another informant believed her husband's clothes when he returned from working as a migrant worker in Hong Kong. ${ }^{46}$

${ }^{41}$ Sakura, Interview, October 09, 2017. Nining, Interview, October 12, 2017.

${ }_{42}$ Mawar, Interview, September 30, 2017. Anggrek, Interview, October 05, 2017. Kenanga, Interview, 3 Ockober 2019.

${ }^{43}$ Tina, Interview, September 29, 2017. Wati, Interview, October 11, 2017.

${ }^{44}$ Tina, Interview, September 29, 2017.

45 Tina, Interview, September 29, 2017. Mawar, Interview, September 30, 2017. Anggrek, Interview, September 30, 2017. Kenanga, Interview, October 03, 2017.

${ }^{46}$ Nining, Interview, October 12, 2017.

\section{Wife's View to Husband's Nonmaterial Obligations}

In addition to having material obligations to his wife, a husband also has nonmaterial obligations. This husband's duty is because he is the leader in the household. This husband's leadership in the Quran al-Nisâ' [4]: 34 is called qawwam, which means leader, the person in charge. As a leader, a husband is obliged to educate, guide, love, and respect family members, especially his wife. ${ }^{47}$

The results of interviews with informants indicated that eight wives had never received education from their husbands. Husbands are busy with work and are more active with themselves. Some husbands never educate their wives during marriage life, so their husbands look immature and do not have the family's initiative according to information. ${ }^{48}$ Even a husband who has received a religious education has stayed in one of the Islamic boarding schools but has also never provided religious education; even after marriage, he often leaves prayer. ${ }^{49}$

The nonmaterial obligations of the husband include providing religious instruction to his wife and children. A husband should have more religious knowledge so that he can provide religious education to the family. With sufficient spiritual understanding, the husband can guide and direct him towards the right path. If the husband cannot teach himself because of his busy life earning a family, he allows his wife to follow majlis taklim or scientific halaqah..$^{50} \mathrm{~A}$ husband needs to realize that the wife's position in the family is also essential as an educator for his children.

Interviews in the field with informants concluded that husbands never guide their wives in religious matters. For example, an informant said: "untuk Shalat yo dewe- dewe, gak pernah ngelingno" (For praying, it was performed

47 The husband is responsible for the wife's character and behavior. Miftah Faridl, Rumahku Surgaku, Romantika dan Solusi Rumah Tangga, (Jakarta: Gema Insani, 2007), $5^{\text {th }}$ print , p. 114.

${ }^{48}$ Tina, Interview, September 29, 2017. Mawar, Interview, September 30, 2017.

${ }^{49}$ Anggrek, Interview, September 30, 2017.

${ }^{50}$ Cahyadi Takariawan, Pernak Pernik Rumah Tangga Isalami, (Solo: Intermedia, 2011), p. 70. 
individually and never reminded). ${ }^{51}$ While other husbands do not remind or invite them to pray in the congregation, even the wife often reminds her husband to pray when the prayer time runs out. ${ }^{2}$

One form of the husband's guidance to his wife is to give good advice. For example, a husband advises his wife always to stay away from immorality. The simplest model in everyday life is ordering a wife to pray. His words: "Perintahkanlah keluargamu untuk melaksanakan shalat dan bersabarlah dalam menegakkannya"। Command your family to pray and be patient in enforcing it (Q.S. Thaha [20]: 132). And also the word of Allah: "Berilah peringatan kepada karib kerabatmu yang terdekat"/Give warnings to intimates your closest relatives (Q.S. alSyu'ara'[26]: 214).

The husband's nonmaterial obligation to his next wife is respect. The author gets information that husbands do not respect their wives. They do not involve their wives in making decisions in the household. One of the husband's attitudes in respecting his wife is to invite his wife to discuss the family home matters. All family matters are discussed and decided together. Each party, husband and wife, must listen effectively and not easily judge the good or bad of the opinion expressed by either party. Both of them should look for the best solution best collectively on mutual understanding, and both of them do not feel defeated or won. ${ }^{53}$ Listening to the wife's suggestions and accepting her excellent opinion for the family's benefit can strengthen husbandwife relationships, reassure her feelings and give the impression that the wife has a role in the household and has responsibilities towards the family.

Communication within the informants' families did not go well because the wives were never invited to deliberate on household matters. A husband always makes household decisions without involving his wife, and he discusses

\footnotetext{
${ }^{51}$ Kenanga, Interview, October 03, 2017.

52 Mawar, Interview, September 30, 2017. Sakura, Interview, October 09, 2017. Nining, Interview, October 12, 2017. Wati, Interview, October 11, 2017. Tina, Interview, October 29, 2017.

${ }_{53}$ M. Quarish Shihab, Pengantin Al-Qur'an: Kalung Permata Buat Anak-Anakku, (Jakarta: Lentera Hati, 2007), p. 141.
}

household problems with his biological mother. ${ }^{54}$ When his wife asked for deliberations, some avoided it because they felt it was not essential to discuss it. ${ }^{55}$ As for others, for example, when the wife lived in Ponorogo with her child, when her husband called, she asked him to talk to her child to encourage her child to go to school, but her husband said: "Jangan mengatur diriku” (don't manage me)..$^{56}$ It shows that good communication is the key to harmony in the household. Therefore, there is no good communication between husband and wife.

Good communication or deliberation is the Quran recommendation to solve any problems faced, including family problems.57 As the household head, the husband should be open to his wife's suggestions and input. A husband does not need to be ashamed or feel inferior to accept his wife's information when the wife gives a better view than her opinion. A good leader will value and implement better and more reasonable ideas and suggestions that benefit more. Rejecting and belittling the opinions and recommendations of the wives shows a form of the husband's arbitrariness.

The next duty of the husband to his wife is to love his wife. The husband, as the head of the household, is obliged to love his wife. Husband's love for his wife in the home can be manifested in the form of concern for his wife, being gentle, speaking politely, and not hurting. As the head of the family, a husband is obliged to intercourse and treat his wife well. Husbands view wives as life partners, friends who complement each other in the household.

During the marriage, several informants felt that they did not get attention from their husbands. She is more preoccupied with work and affairs; some have never received a physical and mental income. Usually, husbands often leave the house and rarely come home; some come home from work at night the next day; they work again. His house seems like a boarding house for him..$^{8}$

\footnotetext{
54 Kenanga, Interview, October 03, 2017.

55 Wati, Interview, October 11, 2017.

56 Tina, Interview, September 29, 2017.

57 M. Quarish Shihab, Pengantin Al-Qur'an..., p. 148.

${ }^{58}$ Tina, Interview, September 29, 2017. Anggrek, Interview,
} 
The form of the husband's affection and paying attention and how is the husband's attitude towards his wife is little. There was an informant when she was pregnant; her husband did not want to take her to the doctor for a checkup; the one who delivered her was her parents..$^{59}$ When she was pregnant, she conveyed her desire to her husband that she wanted to eat young coconut, mango, and peel, but her husband did not comply. When you want something, be it food or medicine that you need when you are sick, you rely on asking your parents for help. Until getting pregnant for the first child, even more, parents help both for the cost of antenatal care and birth. Meanwhile, for the second pregnancy, the informant financed himself from his savings. ${ }^{60}$

Husband's love for his wife also lacks in the form of words and deeds. Some wives often get harsh words from their husbands, cursed at and uttered with dirty dishes. He even threw his cellphone and slammed him. So that one of the reasons for the filed for divorce is the problem of domestic violence (KDRT). ${ }^{61}$ Another informant was once scolded by the husband when he ate because the wife had finished eating first, so that the wife was splashed with dishwashing water, ${ }^{62}$ and there was also when she got angry she said harsh words..$^{63}$ It shows that husbands' treatment towards their wives shows a lack of attention and does not hesitate to act harshly.

A husband as the head of the household is obliged to treat his wife well as it is said in the Quran: wa'asyiruhunna bil ma'rûf (legally respect your wife). In the context of a family, mu'asyarah means an annoyance between husband and wife. In the process of negotiation, both of them must be balanced between husband and wife. In connection with the pattern of mu'asyarah relations between husband and wife, the Quran states that the relationship between husband

October 06, 2017. Wati, Interview, October 11, 2017, Sakura, Interview October 19, 2017.

59 Mawar, Interview, September 30, 2017.

${ }^{60}$ Kenanga, Interview, October 03, 2017.

${ }^{61}$ Nining, interview, October 12, 2017.

62 Kenanga, Interview, October 03, 2017.

${ }_{63}$ Tina, Interview, September 29, 2017. Wati, Interview, October 11, 2017. and wife is based on the principle of partnership, where the existence of both is complementary, the focus of justice is always upheld everywhere and under any circumstances. The relationship between husband and wife is not limited to sexual relations and an ideally full interaction; mature in attitude towards spouses, family, and children are mature when someone can behave wherever people are located.

Mu'asyarah bil ma'rûf has the meaning of togetherness between two parties, carried out based on goodness. It can happen to relatives, friends, friends, husband and wife, family, etc. The scope of mu'asyarah bil ma'rûf also exists in society's cultural and traditional situations and conditions. When life is based on compassion and in the right way, although living among many souls with different characters, with various ambitions, will undoubtedly be passed well. Combining two different genders is not an easy matter, but therein lies nature (fitrah) outlined by Allah for men and women so that they can live together in a sacred and lawful bond, namely marriage.

Compilation of Islamic Law Article 77 explained husband and wife's obligations as follows: first, husband and wife have a noble responsibility to uphold a sakinah, mawadah, and rahmah household as the foundation of the basic structure of society. Second, husband and wife are obliged to love each other, respect, be loyal, and provide physical and mental assistance to each other. Third, husband and wife have to care for and care for their children, both in terms of their physical, spiritual, and intellectual growth to religious education. Fourth, the husband and wife are obliged to maintain their honor. Fifth, if the husband or wife neglects their obligations, each of them can file a lawsuit at the Religious Court.

\section{Conclusion}

The wife's view of the husband's material obligations is that the husband does not fulfill his duties. Eight informants filed for legal divorce because their husbands did not provide for them. The period the husband does not provide a variety of income. Two informants admitted 
that their husbands had not given a living while married. An informant stated that while she was married, her husband only lived for three months. Meanwhile, two other informants admitted that since filing for divorce, the two of them had not been given support by their husbands for almost two years.

According to informants, wives and husbands do not carry out nonmaterial obligations as their family's responsibilities. The nonmaterial husband must educate, guide, respect, protect, and cherish the wife. According to the informants, they did not care about their duties in providing education and guidance. They also do not respect their wives because they do not want to involve their wives in making decisions related to family and household. They also do not love their wives because they often speak harshly, and some even act harshly. They are more concerned with their affairs and less attentive to their wives.

\section{Reference}

Ahmad, Idris, Fiqh Syafi'i, Jakarta: Karya Indah, 1986.

Diknas, Kamus Besar Bahasa Indonesia, Jakarta: Balai Pustaka, 2002.

Faridl, Miftah, Rumahku Surgaku, Romantika dan Solusi Rumah Tangga, Jakarta: Gema Insani, $5^{\text {th }}$ print, 2007.

Ghazali, Abdur Rahman, Fikih Munakahat, Jakarta Timur: Prenada Media, 2003.

Hamka, Kedudukan Perempuan Dalam Islam. Jakarta: Pustaka Panjimas, 1983.

Indrijati, Nurul Afni Herdina, "Pemenuhan AspekAspek Kepuasan Perkawinan pada Istri yang Mengcerai gugat", Jurnal INSAN, vol. 13, no. 03, Desember 2011.

Jaziri, Abdurrahman, Al-, Al-Fiqh 'Ala Madzahib Al-Arba'ah, Beirut: Dar al-Fikr, Juz. IV, t.th.

Kurniawan, Harry dan Maisuriati, "Dasar Pertimbangan Hakim Dalam Putusan Perkara Cerai Gugat Suami Mafqud (Analisis Putusan Nomor 0205/Pdt.G/2016/MS.Ttn)", Jurnal Al-Murshalah, vol. 3, no. 1, Januari - Juni 2017.
Lubis, Ali Akhbar Abaib Mas Rabbani, "Nikah Mutah: Kontekstualisasi Narasi dan Nalar Nikah Mutah", Istinbath, vol. 19, no. 1, 2020.

Ma'luf, Luis, Al-Munjid fi al-Lughat wa al-l'lam, Beirut: al-Syirkiyah, 1986.

Muawwanah, Rohana, "Realitas Gugat Cerai TKW (Asia Timur) di Kabupaten Ponorogo: Sebuah Tinjauan Hukum Islam". Edugama: Jurnal Kependidikan dan Sosial Keagamaan", vol.5, no. 2, Desember 2019.

Muhammad, Husein, Fiqh Perempuan Refleksi Kiai atas Wacana Agama dan Gender. Yogyakarta: LKiS, 2007.

Mukhtar, Kamal, Asas-asas Hukum Islam Tentang Perkawinan. Jakarta: Bulan Bintang, 1987.

Munawir, Ahmad Warson. Kamus al Munawwir. Yogyakarta: Pondok Pesantren al- Munawir, 1984.

Prianto, Budhy, Nawang Warsi Wulandri, Agustin Rahmawati, "Rendahnya Komitmen dalam Perkawinan sebagai Sebab Perceraian", Jurnal Komunitas: International Journal of Indonesian Society and Culture, vol. 5, no. 2, 2013.

Rini, Q.K. \& Retnaningsih, "Keterbukaan Diri dan Kepuasan Perkawinan pada Pria Dewasa Awal", Jurnal Psikologi, vol. 1, no. 2, 2008.

Rofiq, Ahmad, Hukum Islam di Indonesia, Jakarta: PT Raja Grafindo Persada, 1997.

Syarkawi, Al-, Al-Syarkawi 'ala al Tahrir, tk: alThaba'ah al Nasyr wa al Tauzi, tt

Syatha, Abu Bakar Muhammad, l'anah al-Thalibin, Beirut: Dar al- Fikr, Juz 4, 2005.

Takariawan, Cahyadi, Pernak Pernik Rumah Tangga Isalami, Solo: Intermedia, 2011.

Tim Redaksi, Kamus Besar Bahasa Indonesia, Jakarta, Balai Pustaka, $1^{\text {st }}$ print, 2001.

Ulfah, Isnatin, "Menggugat Perkawinan: Transformasi Kesadaran Gender Perempuan dan Implikasinya terhadap Tingginya Gugat Cerai di Ponorogo", Kodifikasia, vol.5, no. 1, 2010.

Wardatun, Atun, "The Social Practice of Mahr among Bimanese Muslims: Modifying Rules, 
Negotiating Roles," Edited by John R. Bowen and Arskal Salim, Women and Property Rights in Indonesian Islamic Legal Context. Leiden: Brill, 2019.
Yunus, Mahmud, Hukum Perkawinan dalam Islam Menurut Madzhab Syafi'i, Hanafi, Maliki, Hambali, Jakarta: Hidakarya Agung, 1991.

Zuhayli, Wahbah, Al-, Al-Figh Al-Islam wa Adillatuh, Kairo: Dar Al-Fikr, Juz. VII,1989. 